Historical Notes

\title{
Revisiting the Calendar Tradition of Ancient India
}

\author{
B N Narahari Achar*
}

(Received 18 April 2015)

\begin{abstract}
A recent model for the calendrical tradition of ancient India has been examined with particular reference to yajña ritual.

Key words: Calendar tradition, Caitrādi scheme, Heliacal rising, Naksatra, Pancānga, Yajña ritual
\end{abstract}

\section{INTRODUCTION}

By the term Calendar, which comes from Latin, calendarium, meaning an account book, we understand a system of determining the beginning, length and divisions of a year, and a table of some sort that shows the days, weeks and months of a given year. We then try to fit what is essentially a western concept with something which resembles it in the Indian context and call it the Calendar tradition of India. Thus the problem becomes one of identifying the beginning of the year, its length, its divisions etc. It is pointing the obvious when we say that calendar (i.e., the tables we use the Gregorian calendar, for example), simply lists the beginning of the year as January 1, the months and days of the week. In the US, the calendar is important for April 15, the Tax day. Some holidays are celebrated on fixed dates, Such as the Independence day, or Christmas day, but some are celebrated on fixed day of the week, such as the Thursday celebration of Thanksgiving Day. Except for determining the Easter, New Moons, Full Moons etc. do not matter at all. Most other celebrations are done on Mondays only. But other religious calendars such as the Jewish, or Muslim calendars do consider New Moons, Full moons, some consider intercalary months, others do not.
In the Indian context, there is the pancāñga, a very complex compendium of "five parts", tithi, vāra, naksatra, etc. But this tradition is only about 1500 years old. What was the tradition during the Vedic times? Dikshit (1969) had already addressed the issues connected with the so-called Vedic Calendar, but without attaching a chronology to it.

In a recent article Bag (2015) has expounded on the calendrical tradition of India going back to the Vedic times, giving an overview of the important results and in the process has established a chronology for the Vedic tradition. According to him there are textual traditions belonging to rgveda samhita, the yajurveda samhitā, the brāhmanas and the vedānga-jautișa fixed at $6500 \mathrm{BC}, 5000 \mathrm{BC}, 2500 \mathrm{BC}$ and 1000 $\mathrm{BC}$ respectively. The Harappan tradition fixed at c. 2000 BC followed the yajurveda tradition. It will be interesting to review the evidence presented by him and to examine where the date of the mahābhärata war fits in the scheme of things, since Bag appears to draw substantially from Bhatnagar, who gives a date of $1793 \mathrm{BC}$ for the war.

It is indeed surprising that Bag begins with a discussion of the Babylonian system, with

\footnotetext{
*University of Memphis, Memphis, TN 38152, USA
} 
twenty four (or eighteen, according to some) star systems along the ecliptic on the basis of MulApin (c. 700 BC) when it is known that the Indian system is substantially more ancient by several thousand years. It would have been more natural to start with the older system first. But his choice, which is a hangover from the discussions of nearly a hundred years ago, carries with it the whole unnecessary controversy about the origin of the naksatra system which plagued the literature then.

Bag states that rgveda "has also reference to a few naksatras like āśvayujau (RV.I.3.1; III.58.1-9), pusya (RV. I.42.1; VI.54.2), aghā (or maghā), arjunī (or phālguni) (RV. X.85.13), suggesting that the prominent naksatras were possibly known (emphasis added by the author) as a part of the zodiacal system during the time of rgveda." That the Indians had first recognized only six stars (in rgveda), then raised to twenty eight or twenty seven nakșatras (definitely in taittirīya samhita) seems to be the driving hypothesis for his classification into rgveda and yajurveda samhita traditions.

\section{THE ENTIRE SYSTEM OF NAKŞATRAS IS KNOWN IN RQGVEDA}

It has been shown by the author that such a hypothesis that only six were known in rgveda but the complete system was known in taittiriya is without a basis, but the entire list can be traced to rgveda (Achar, 2000a, 2002, pp. 361-377; 2003, pp.183-193).

The clue that the entire system is known in rgveda is provided by the vedānga-jautisa $(\mathrm{VJ})$. It is known that each naksatra is associated with a presiding deity. A naksatra can be addressed either by its name or by the name of the deity. In $\mathrm{VJ}$, there is one list, where some naksatras are addressed by the first or the last letter of their name, but some others are addressed by the first or the last letter of the name of the deity. It is very clear in the context which nakșatra is meant. There is also a second list, where every naksatra is referred to by a letter of the name of the presiding deity only. Now in rgveda we do find the actual names of six naksatras, but as the author has shown, there are lists of deities which actually correspond to the 27/28 naksatras. The details can be obtained from the author's papers cited. Thus the entire list of naksatras is known in rgveda.

\section{Heliacal Rising and yearning for NON-VISIBILITY OF $A \dot{S} V I N \bar{I}$}

Bag's central theme is that rgveda refers to heliacal rising of aśvayujau at Winter solstice and he cites :

.....putraścarati dakșināayāh

$\bar{a}$ dyotanìm vahati śubhrayāmoșasah stomo aśvināvajīgah|| RV III.58.1

'(aśvināyujau), the son of dakșināyana, has entered into the sun, then carries the white dazzled day-maker sun with it, when the reciter of aśvināyujau are getting assembled before dawn'.

Bag continues and says that it refers to aśvini nakșatra ( $\beta$ Arietis) as the son of daksināyana (South point or Winter solstice) and its heliacal rising with sun at dawn an important event for the reciter(s) who had assembled for observation. It is a special type of ritual connected to a year beginning at the winter solstice. The ritual was to observe the Heliacal Rising (the first seeing) of aśvini , when they emerge from behind the sun on the eastern horizon before sunrise. The aśvins then represented the Winter Solstice.

According to Bag, rgveda also records yearning by the worshippers for aśvinī is no longer being seen at the Winter solstice in the early morning and he cites RV. V. 74.1-2 and refers to the Sky Map given by Bhatnagar for December 7000 BC in support of his hypothesis.

Bag then argues that as time passed, because of precession, Winter solstice no longer 
occurred at aśvinī, but had moved to revati which is rather faint. So the Vedic people then chose a new marker, Summer solstice at citrā and chose full moon at citra as a reference point and that is the beginning of caitrādi scheme. However all this speculation still leaves why and how the lunar months were restricted to only 12 unclear. In any case, Bag says that the yajurveda now contains all the 27 naksatras and the date when the caitrādi scheme became popular is $6000 \mathrm{BC}$. So he labels this as the yajurveda samhita period. Bag gives the list of naksatras and their identification with the modern names in star catalogs made in the Report of the Calendar Reform Committee (Saha and Lahiri, 1955).

Unfortunately the whole thesis seems to be based on a misidentification. He does not identify what exactly is the ritual connected to a year beginning at the winter solstice except to say that it is a special type of ritual. (Perhaps it is the gavämayana sattra). But the rk RV.III.58.1 he has quoted can be looked up. It is the $58^{\text {th }}$ sükta in the third mandala, viśvamitra is the rṣi, aśvinau are the twin devatas, and it is in tristup chandas. It has nine rks. Most importantly its viniyoga says that it is to be used for aśvinaśastra recitations of tristup chandas in connection with aśvina kratu at the time of prātaranuvāka recitations in connection with the prātassavana, morning libations of soma juice pressing on the day of soma juice pressing in a somayajña which forms a part of the sattra.

We will give a brief outline of the ritual connected with the recitation of this mantra and it will then become clear that the whole interpretation of Heliacal rising at winter solstice and yearning for the disappearance of aśvinis might not be appropriate.

\section{The institution of SOMAYAJÑ}

Yajñ in the simplest terms involves the tyāga (the giving up) of some dravya (material possession) of the yajamanna (the sacrificer) to the devata (deity) through the medium of agni (fire) to the accompaniment of recitation of mantras. This is the outer ritual, but there is a deep inner significance to this ritual, which is not easily understood, as has been emphasized by Aurobindo (1971).

There are three groups of yajña s, depending on the type of offering made to fire in the ritual: (a) haviryajña (b) pākayajña and (c) somayajña. Each of these in turn consists of seven subgroups of yajñas

agnyādheya, agnihotra, darśapūrnamāsa, āgrayaṇa, cāturmāsya, dākșāyaṇayajña, and sautrāmaṇi belong to the first group, haviryajña group. The offering consists of "havis", such as milk, clarified butter, food- grains, etc.

aupāsana, vaiśvadeva, pārvaṇa, aștaka, māsiśrāddha, sarpabali, and ìsānabali belong to the second group, pākayajña. The material offerings include cooked food-grains.

somayajñas in which the offering is the juice of the crushed soma plant made to the deity. Soma are further divided into

(i) aikāha those that are completed in one single day

(ii) ahina, those that require from two to twelve days for completion

(iii) satra, those that require more than twelve days.

The soma yajña the most important of all yajñas, is further divided into seven types:

agniștoma, atyagniștoma, ukthya, sodaśin, vājapeya, atirātra, and aptoryāma .

All these are already well known in the rgveda samhita, for example, RV(I. 20. 7) refers to the twenty one yajnas mentioned above:

sunvate"

"teno ratnāni dhattana trirā sāptāni 
"Confer therefore, riches and accomplish the thrice seven-fold sacrifices."

The details of performance of all the twenty one yajñas are described in the brāhmana texts.

Our main concern here is the agnistoma. Agnistoma is considered the basic or the fundamental one, prakrti, and the remaining six are its variants, vikrti. Agnistoma forms an integral part of Jyotistoma, which lasts for five days, and sometimes the two are often identified (Kane, 1997). We use these terms inter-changeably when there is no confusion and describe the five day ritual.

In agniștoma, there is one yajamāna (sacrificer) and sixteen rtviks (priests). The rtviks belong to four vargas (groups) of four each, specializing different aspects of the soma yajña:

(a) Hoț varga: hotā, maitrāvarun̄ā, acchāvāka, and grāvāstut, reciters of the rk mantras.

(b) Adhvaryu varga: adhvaryu, pratiprastotā, $n e s t a \bar{a}$, and unnetā, the director of the ceremony and his assistants specializing in the yajus mantras

(c) Udgātr varga: udgātr, prastotā, pratihartā, subrahmanya, singers of sāma

(d) Brahma varga: brahmā, brāhmañācchāmsī, agnìdhra and potā. Brahma with his group oversees the whole ritual to make sure the whole ritual is carried out without a hitch.

\section{Five dAYS OF JYOTIȘTOMA}

The ceremonies performed during the five days are as follow:

First day - preliminary ceremonies selection and appointing of the rtvigs (priests), welcoming them with madhuparka, dīksāayanìya $i s \underline{t} i$ and $d \bar{\imath} k s \underline{a}$.

Second day-The prāyaṇya iști or the opening iști, the buying of soma; attithyești, the ceremony to welcome soma, who is treated as a king with all the attendant honors; pravargya and upasad. These two rituals are to be done twice, once in the forenoon and once in the afternoon. Pravargya is an independent ritual and is supposed to grant the yajamāna a celestial body. Upasad is also a special ritual and both of these rituals are characterized as apürva. There are very strict rules of conduct regarding food, mating etc., to be followed, sometimes for up to a year, by a person who has performed these two rituals. These two are to be performed twice a day until the day previous to soma pressing.

Third day-pravargya and upasad are both repeated twice once in the morning and once in the afternoon.

Fourth day-On this day both pravargya and upasad are performed twice all in the morning itself and all the paraphernalia connected with these two are discarded in a $u d v \bar{a}$ sana ceremony. The next step is agni pranayanam, the ceremony to bring agni from the âhavaniya to the uttaravedi. The original àhavaniyas treated as the gārhapatya during the somayāga ritual. The preparations for somayāga begin with the agni-soma pranayanam, havirdhana pranayanam followed by a sacrifice to agni and soma.

Fifth day- The day of soma pressing, is

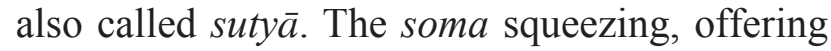
and drinking of soma juice at three great libations, prātassavana in the morning, mādhyandina savana, the midday pressing and trtiya savana, in the evening. These are followed by the concluding udayaniya iști and the ablution, avabhrta.

\section{Recitations ON THE SUTYĀ DAY}

The recitations take place at the three times of soma squeezing depicted in Table 1.

There are twelve stotras (mantras from sāmaveda samhita) sung by the udgātr group on the day of soma pressing. For each stotra, the hotr group recites a set of riks from rgveda called 
Table 1

\begin{tabular}{|c|c|c|c|c|c|}
\hline \multicolumn{2}{|c|}{ prātassāvana } & \multicolumn{2}{|c|}{ mädhyandinasavana } & \multicolumn{2}{|c|}{ trtīya sāvana } \\
\hline stotra & śastra & stotra & śastra & stotra & śastra \\
\hline bahispavamāna & $\overline{a j j y a}$ & mādhyandina pavamāna & marutvatīya & arbhava pavamāna & vaiśvadeva \\
\hline$\overline{a j y} a$ & pra uga & prastha & niṣkaivalya & agniṣtoma sāman ${ }^{l}$ & āgnimāruta \\
\hline$\overline{a j y} a$ & $\overline{a j j y a}$ & prastha & niṣkaivalya & & \\
\hline$\overline{a j y} a$ & $\overline{a j y y a}$ & prastha & nișkaivalya & & \\
\hline$\overline{a j y} a$ & $\overline{a j j y a}$ & prastha & niṣkaivalya & & \\
\hline
\end{tabular}

śastras. Thus there are twelve śastras in agnistoma. Of these, there are 4 ajjya śastras, 4 niskaivalya śastras, pra uga, marutvatīya, vaiśvadeva and agnimāruta making up the required 12 number. Pra uga śastra is recited together with ajjya sastra in the morning, marutvatiya and nickaivalya in the afternoon pressing, and the vaiśvadeva and agnimäruta śastras at the time of the evening pressing. The table above gives their distribution at the three libations

The number of stotras and sastras increase for the variants of somayajña, for example the required number for atirātra is 28 .

The ceremonies for the soma pressing begin immediately after midnight of the fourth day. On the direction of the adhvaryu, the hotr begins reciting the prātaranuvāka, mantras which are appropriate to be recited for the morning session of soma pressing. This ritual is divided into three parts. The first part is called agneyakratu the prayer for agni. The áśvalāyana śrauta sūtra (4.13.6-4.15.3) gives the details of the particular süktas and individual rks that have to be recited, containing mantras in each of the seven chandas: gāyatri, anuștup, triștup, brhatī uṣnik, jagatī, and pankti, all directed to agni. There is a minimum of at least $100 \mathrm{rks}$ are to be recited. If all the sūktas and $r k s$ specified in the âvalāyana sūtra are recited, it would amount to reciting a total of 1324 rks for the aggneya kratu part alone with 320 mantras in gāyatrī and 591 in triștup. Only one $s \bar{u} k t a, \mathrm{RV}(\mathrm{V} .6)$ containing 10 rks is in pankkti meter.
The second part is called usasyakratu and is directed to the deity usas and the third part is called âsvina kratu and is directed to the aśvini deities. Each of these parts in turn consist of $r k s$ again containing mantras in the same seven meters described for āgneya kratu. For example, usasyakratu must have 250 mantras, whereas àsvina kratu requires 407 mantras in the same meters. Thus the prātaranuvāka alone requires the recitation of some $2000 \mathrm{rks}$, roughly the fifth of the contents of the whole of rgveda (Kane, 1997).

The prauga sastra is the recitation appropriate to the seven deities $v \bar{a} y u$, indra-vāyu, mitra-varuna, aśvini, indra, viśvedevāh, and sarasvati $\bar{l}$, the so-called prauga devatas. The recitation consists of three rks in gāyatri chandas for each of the seven deities for a total of 27 separate mantras. After some associated activities, the soma juice is pressed and filled into cups, and offerings are made, all done to the accompaniment of recitation of required mantras.

The mid-day libations, madhyāhnika sâvana is directed to Indra and the recitations involve rks of triștup chandas exclusively. The recitations of marutvatīya śastra followed by four niskaivalya śastras are done according to the prescriptions laid down for example in the aitareya brāhmaṇa.

The evening libations are directed to viśvedevāh and are in jagatī chandas. The recitations include the vaiśvadeva śastra and the agnimāruta śastra which follows the sāma stotra, agnistoma, because of which the entire soma-

\footnotetext{
${ }^{1}$ It is because of this samman, the yajña is called agniștoma
} 
$y a j n ̃ a$ itself is named. The entire ritual is concluded by performing the udayancya iști and finally the ablution, avabhrta.

The important point to note is the complexity of the ritual and the staggering number of $r k s$ required for recitation during the ritual. It is no exaggeration to say that when all the different variations of the somayajña are taken into account, most of the rks of rgveda, if not all, are recited during the performance of this most important of the yajñas.

\section{ThE RQKS QUOTED BY BAG}

The mantras quoted by Bag, RV (III.58.1) and RV(V.74.1-2) are among the 407 mantras to be recited before the sunrise as part of the aśvinakratu, recitations directed towards aśvini deities in the prātaranuvāka ritual at the morning time pressing of the soma juice. This has nothing to do with observing Heliacal Rising of $\beta$ Arietis at Winter solstice. For, the agniștoma somayajña is to be performed in Spring season every year after the New Moon or Full Moon. RV(V.74.1-2) are simply prayers imploring aśvinis to come to the ritual. A simple translation of these two verses is given below:

\footnotetext{
"Divine aśvinis, affluent in praise, descend this day from heaven upon earth, hear that laudation which Atri ever addresses to you, who liberally shower benefits."

"The divine nāsatyās, where are they? Where are they heard of in heaven? To which worshipper do you come? Who may be the associate helping in creating your praises?"
}

As can be seen these are simply prayers urging the aśvinis to come to the ritual.

Dakșināyāh putrah in the mantra RV(III.58.1) does not refer to aśvayujau as son of daksināyana(South point). (Note the dual number aśvayujau, the putrah should have been putrau if aśvini was meant.) The son of the south point refers to the Sun. The whole interpretation in terms of Heliacal rising at Winter solstice is not warranted in this context.

\section{YAJURVEDIC SAMHITA TRADITION AND THE CAITRATI SCHEME}

The hypothesis that the caitrādi scheme of naming months is tied to the Yajurveda is based on the assumptions that aśvini disappeared and a new marker had to be found as the Full Moon at citra and that it is taittirīya samhita that contains the complete list of 27 naksatras. It has been just demonstrated that both of these assumptions are without a basis. Furthermore, the author has discussed (Achar, 2000) the origin of the caitrādi as tied to the concept of yajñ and the entire list of naksatras are to be found in rgveda already.

\section{The List OF NAKSitra IDENTIFICATIONS OF the Calendar Reform Committee}

The list of identification of Vedic naksatras with the stars in a modern catalog, by Indian scholars was first done by the Saha Committee and has been promptly ignored by the Western scholarship led by Pingree and others. While this list has been lauded by Indian scholars, it has been noted by several scholars including the present author that some half-a-dozen identification of stars are completely off, such as Arcturus for $s v \bar{a} t i$, which is almost $40^{\circ}$ away from the ecliptic. Attempts have been made by Abhyankar, Balakrishna and the present author to find a more compatible set of identifications (Achar, 2002).

A dramatic illustration of why the identifications by the Calendar Committee have to be modified is given by the representation of the so-called nakșatriya prajāpati described in taittirīya brāhmaña.

\section{NAKȘATRIYA PRAJĀPATTI}

The passage in Taittirīya Brāhmaṇa (1.5.2.2) depicts the figure of Prajāpati constituting certain naksatras : 


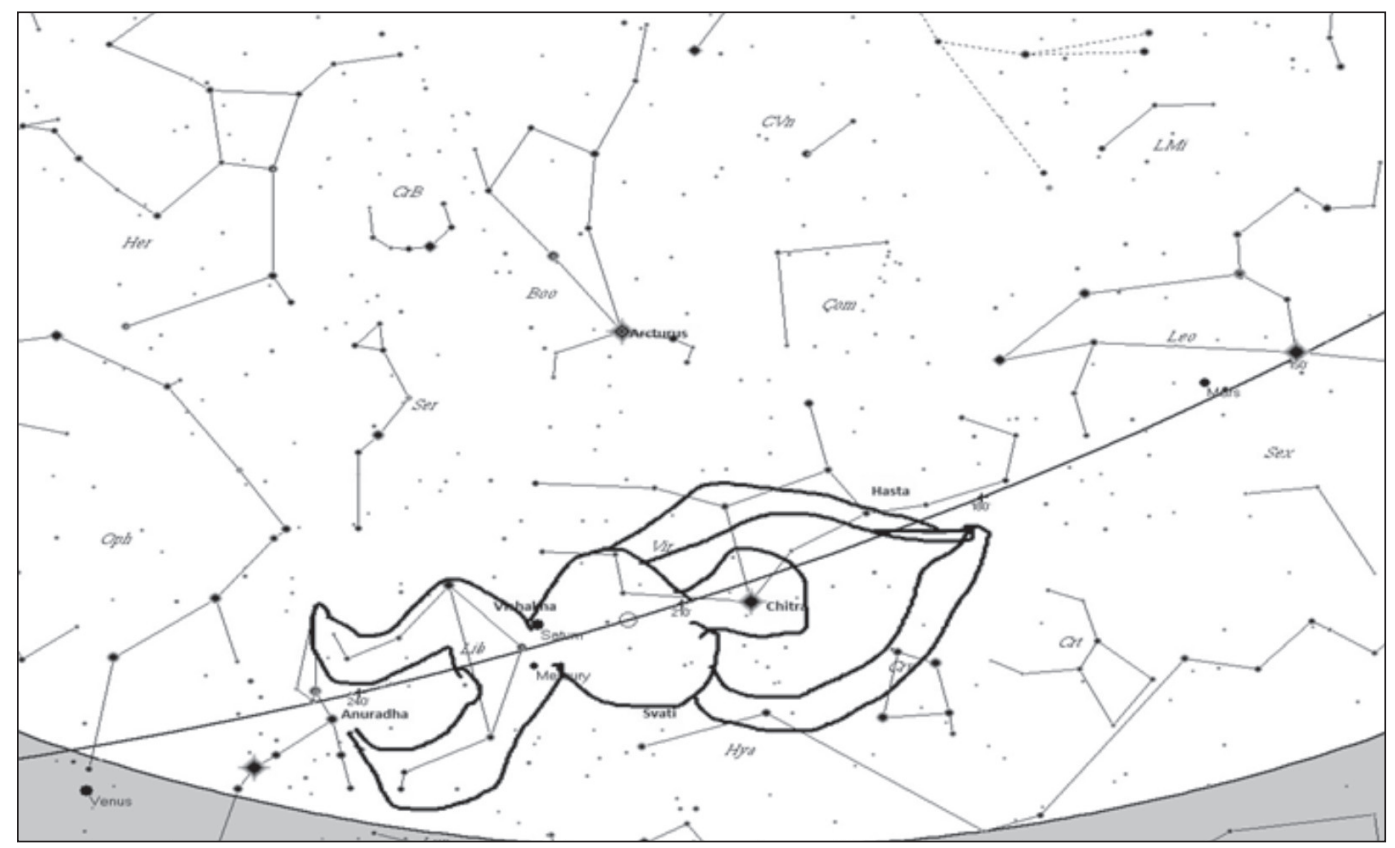

Fig. 1. nakṣatriya prajāpati

yo vai naksatriyam veda| ubhayorenam lokayorviduh| hasta evāsya hastaḥ| citrā sirah niṣtyā hrdayam ūrū viśākhe | pratiṣthānūrāadhāh| eșa vai naksatriyah prajāpatih |

According to this picture, the naksatra hasta represents the hand, citra $\bar{a}$ the head, and niștya (svāti) the heart; the dual vișākhās represent his thighs and anūrādhā represents his feet.

A free-hand sketch of this figure is shown in the fig. $1^{2}$ below in the background of stars and along the ecliptic.

The figure is a classic yoga posture with the folded hands above the head, the naksatras as identified in (Achar, 2000c)match the description very well. It also shows that the commonly accepted identification of Arcturus (alpha Bootes) for svatti is to be rejected as it is too far from the ecliptic to represent the heart of naksatra prajāpati.

\section{VJ TRADITION}

Finally, the date of VJ.
As Bag himself quotes, the date of the vedaniga jautișa may be determined from the position of Winter solstice at śravștha (Dhaniștha)

prapadyete śravișthādau sūryācandramāsāyudak|

sārpārdhe daksiārkas tu māghas-ravanayoh sadāh |RJ6; VJ7

As discussed by Bag in detail, various dates from 1200BC-1400BC have been proposed, but Bag chooses the figure of $1000 \mathrm{BC}$.

Again the dates from 1200- 1400 BC are based on the identifications of the Calendar Reform committee. If the modifications as has been suggested are accepted then the date of $\mathrm{VJ}$ turns out to be about $1800 \mathrm{BC}$. All this has been discussed in detail by the author (Achar, 2000b).

\section{Conclusions}

It has been demonstrated that the particular chronology arrived at by Bag for rgveda samhita, yajurveda saṃhita, brāhmanic and vedānga jautisa traditions as fixed at $6500 \mathrm{BC}, 5000 \mathrm{BC}$, $2500 \mathrm{BC}$ and $1000 \mathrm{BC}$ is not founded on a firm

\footnotetext{
${ }^{2}$ The sky-view pictures have been produced using the Planetarium Software, SkyMap Pro, www.skymap.com.
} 


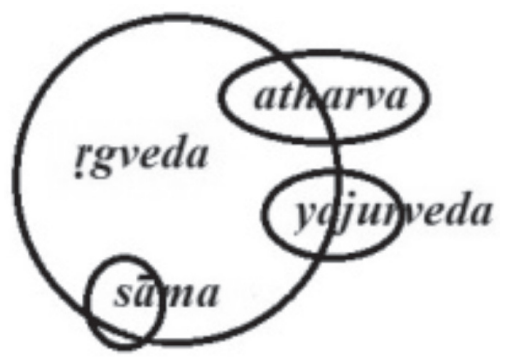

Fig. 2. $r k s$ in all the Vedas. The overlapping regions indicate rks common to rgveda

basis. It is not that the Vedic tradition is not that ancient. The Vedic tradition is in fact ancient and the dates arrived at on the basis of astronomical data by Tilak, Jacobi, Dixit, and more recently by Frawley do point to high chronology. What is objected to is in part to a compartmentalization into rgveda and yajurveda traditions, the latter appearing some 1500 years later based on a model of alleged heliacal risings. Rgveda contains only $r k s$, but the other three also contain $r k s$, in addition to yajus and sāma mantras. Some of the rks in other Vedas are also the same as the ones in rgveda, but other $r k s$ are not found in $r g v e d a$. The diagram in Fig. 2 represents this sharing of rks among the four Vedas. Of course, the $r k s$ themselves may belong to much different times.

\section{BibLIOGRAPHY}

Achar, B. N. Narahari, Searching for Nakshatras in Rgveda, Electronic Journal of Vedic Studies, 6.2 (2000a)

Achar, B. N. Narahari. A case for revising the vedāinga jautisa, IJHS, 35.3 (2000b):173-183

Achar, B. N. Narahari. On the caitrādi scheme, IJHS, 35.4 (2000c): 293-310

Achar, B. N. Narahari, In Search of Naksatras in rgveda in Bhu Dev Sharma (ed), Contemporary Views on Indian Civilization, World Association for Vedic Studies, New Delhi, 2002, pp. 361-370;

Achar, B. N. Narahari, In Search of the Nakshatra's in Rg Veda, Annals of the BORI Vol LXXXIII for the Year 2002, (2003):183-193

Bag, A. K. Early system of nakșatras, Calendar and Antiquity of Vedic and Harappan Traditions, IJHS, 50.1 (2015):1-25.

Dikshit, S. B. Bharatiya Jyotish Sastra, Government of India Press, Cacutta, 1969.

Kane, P. V. History of Dharmașāstra, BORI, Pune, 1997

Kane, P. V. History of Dharmașāstra, vol II part II, BORI, Pune, 1997.

Sri Aurobindo. The secret of the Veda, Sri Aurobindo Ashram, Pondicherry, 1971. 